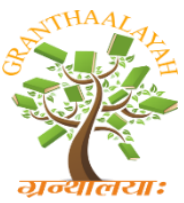

INTERNATIONAL JOURNAL OF RESEARCH GRANTHAALAYAH A knowledge Repository

Science

\title{
EXPERIMENTAL STUDY AND PERFORMANCE OF SOLAR ENERGY SYSTEM WITH GRID CONNECTED POWER SUPPLY
}

\author{
Pradeep Bharti $^{* 1}$, Dr. A.K.Sharma ${ }^{2}$ \\ ${ }^{* 1}$ Research Scholar, Fourth Semester ME (High Voltage Engg.), Jabalpur Engineering College, \\ Jabalpur (M.P) 482011, India \\ ${ }^{2}$ Professor \& HOD, Department of Electrical Engineering, Jabalpur Engineering College, \\ Jabalpur (M.P) 482011, India
}

DOI: https://doi.org/10.29121/granthaalayah.v5.i3.2017.1788

\begin{abstract}
In this paper, we are analyzed about the solar power with grid connection using of various component such as PV Cells battery inverter, and grid power connection, in this way we are connected the grid power and solar power, after that finally we are analyzed the power quality of output with the help of various devices.

Keywords: Word- Solar Energy; Grid Power; Invertor.

Cite This Article: Pradeep Bharti, and Dr. A.K.Sharma. (2017). "EXPERIMENTAL STUDY AND PERFORMANCE OF SOLAR ENERGY SYSTEM WITH GRID CONNECTED POWER SUPPLY." International Journal of Research - Granthaalayah, 5(3), 320-324. https://doi.org/10.29121/granthaalayah.v5.i3.2017.1788.
\end{abstract}

\section{Introduction}

The solar power system are mostly used in rural area because of low maintenance cost, in this way the solar power are used with grid. The final power supplies are achieved. The electrical energy are obtaining from the rays of sun, after that we are achieve the D.C. Voltages, these electrical energy are storages in battery. The 220V A.C. power supply is obtained with the help of invertor, the input of invertor is connected from terminal of battery . The PV system has static and free of moving parts, in this way less maintenance. 


\section{Experimental setup}

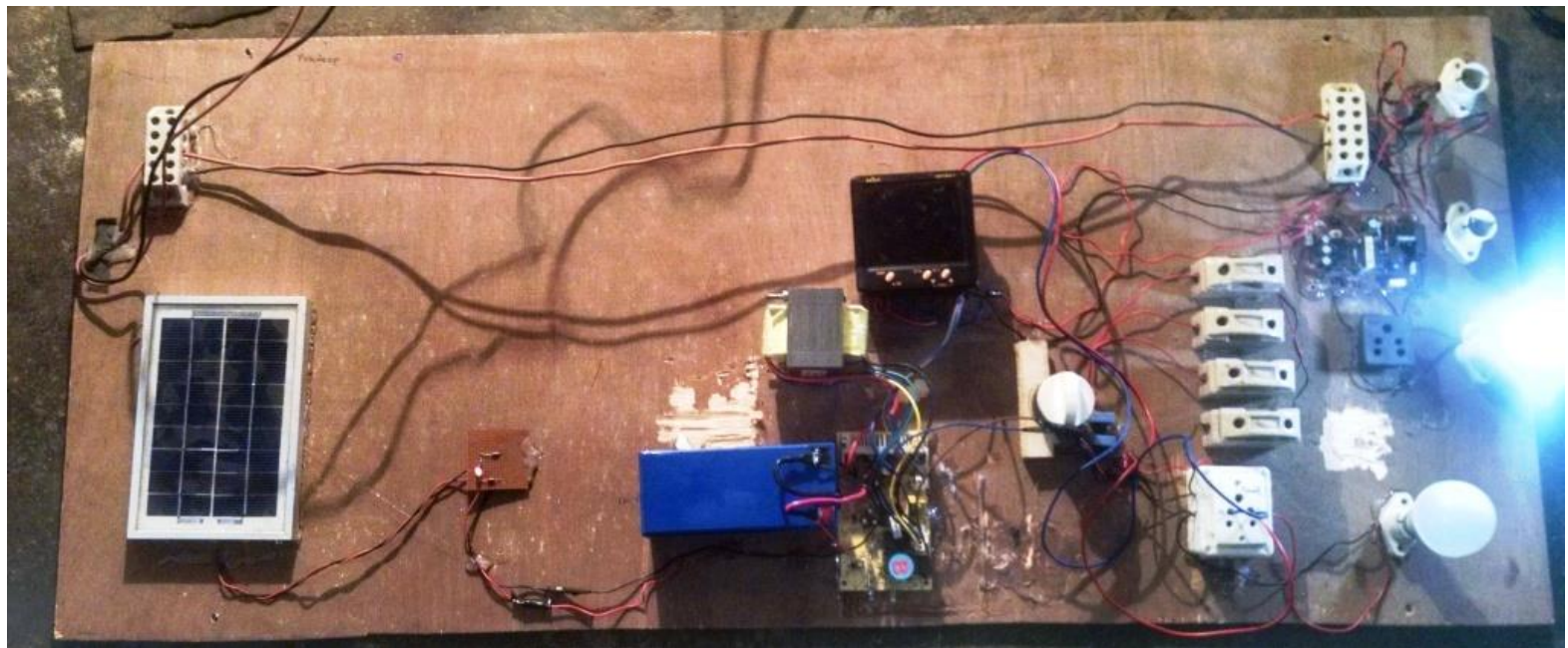

Figure 1: Experimental setup

\section{Components}

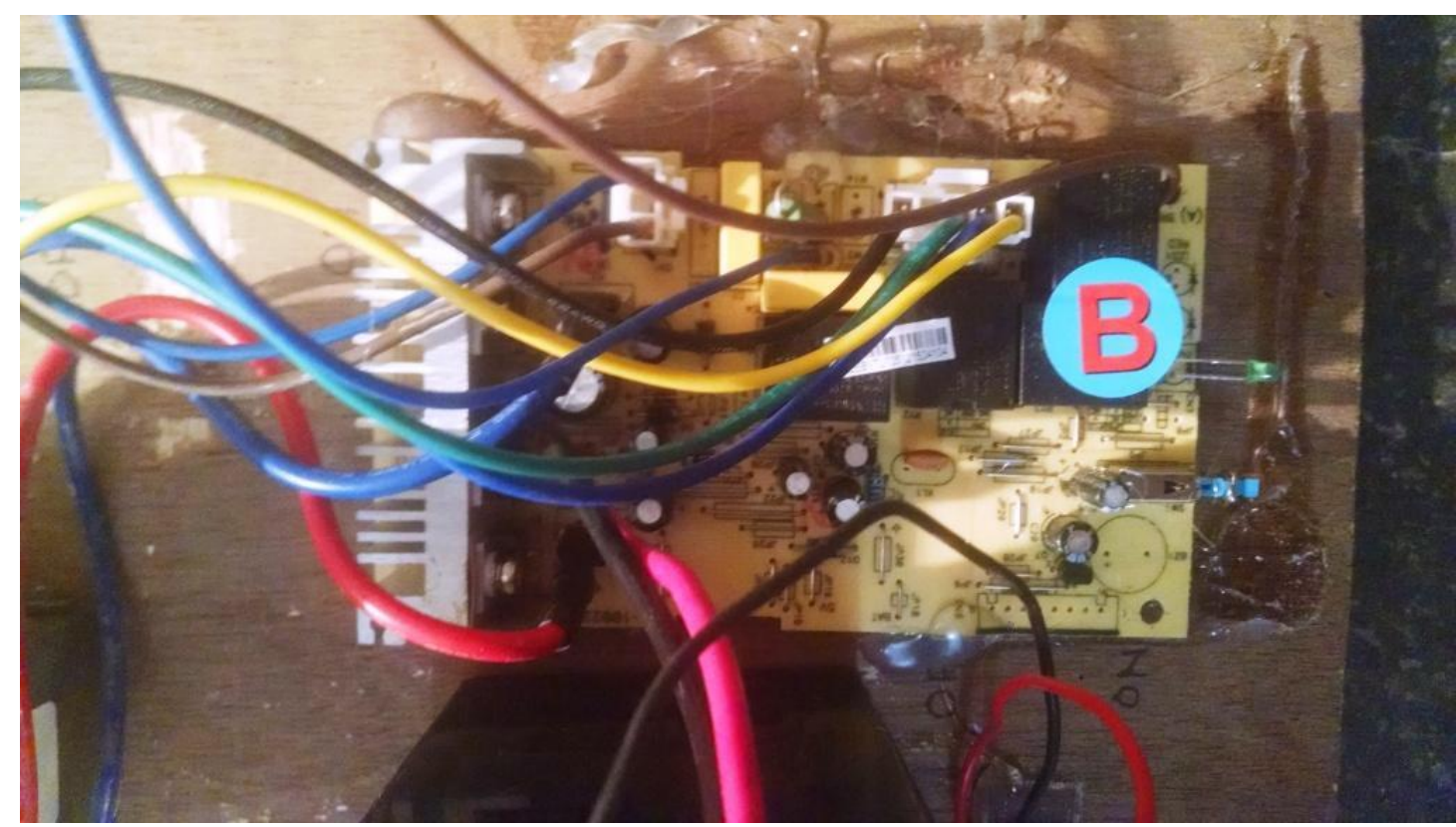

Figure 2: 12VDC to 220VAC Convertor 


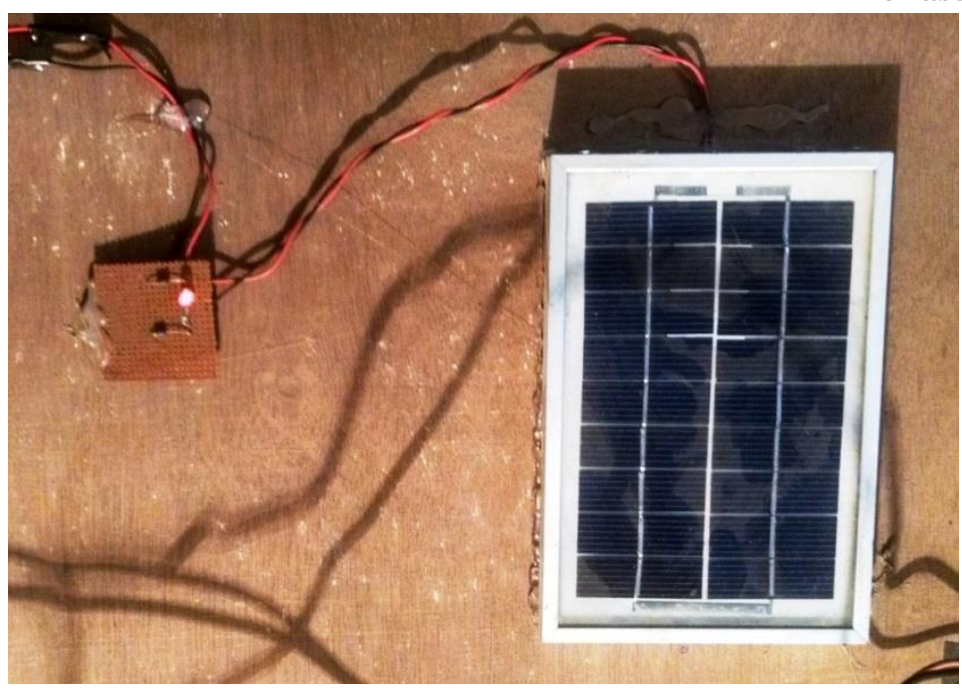

Figure 3: Photovoltaic cells with LED display

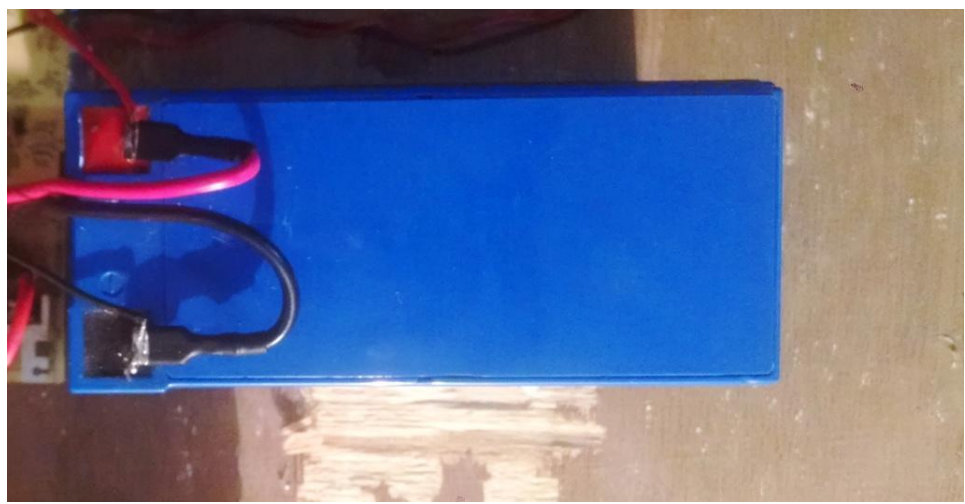

Figure 4: 12VDC battery

\section{Results}

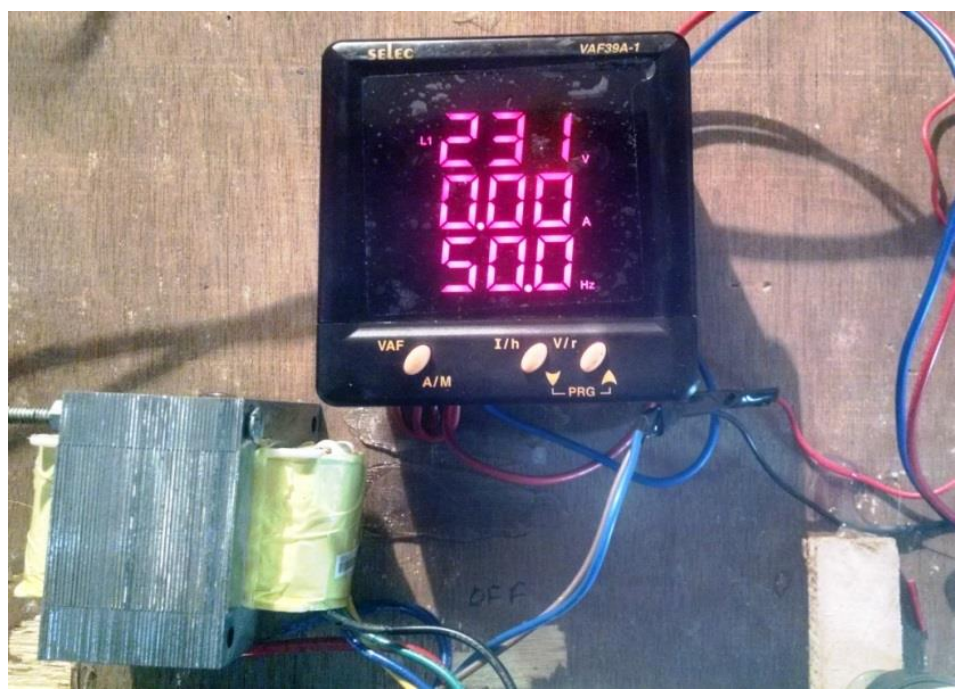

Figure 5: Display of Grid Power 


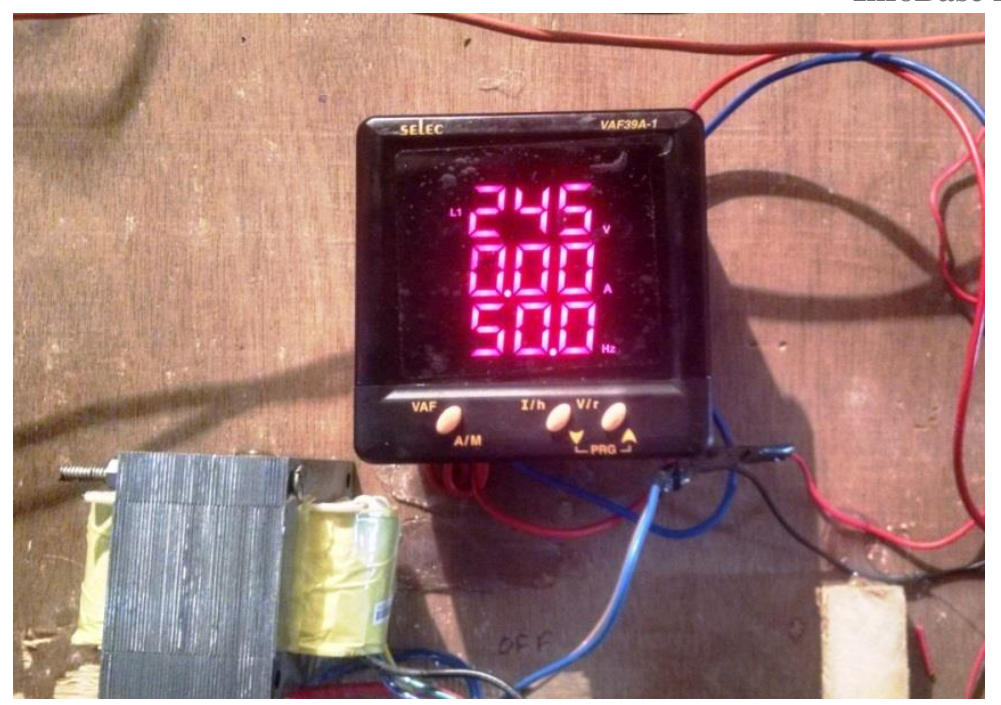

Figure 6: Display of Solar Power

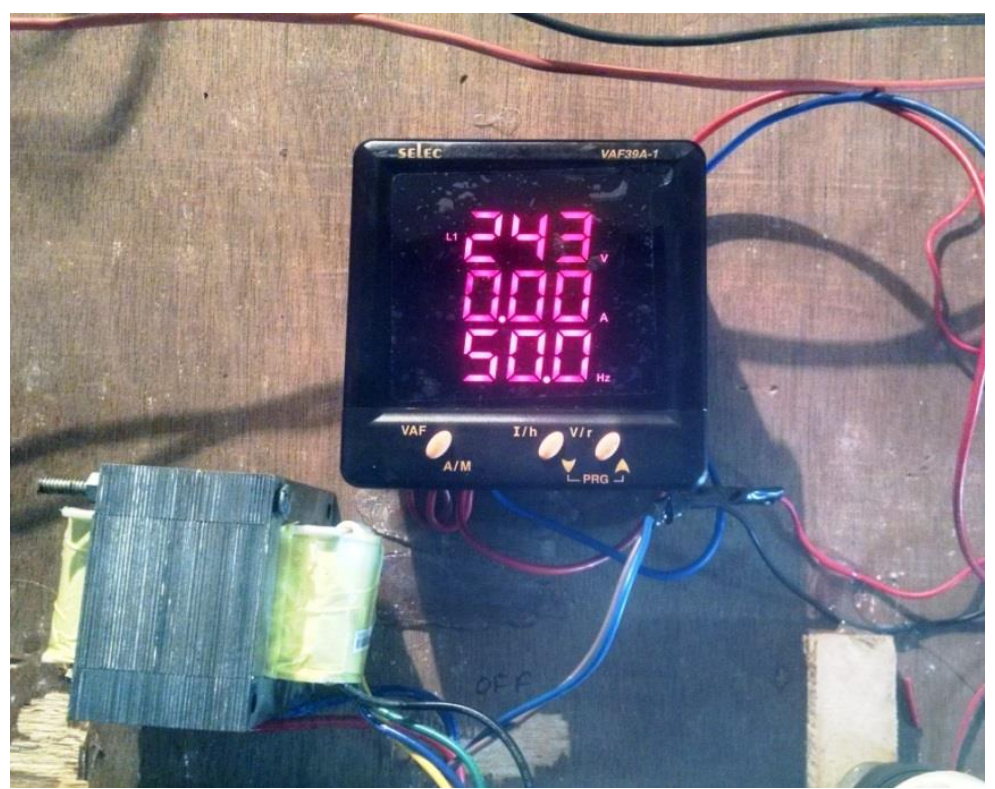

Figure 7: Display of Grid connected solar power system

\section{Conclusion}

We are finding out the 231VAC by Grid power, and 245VAC by solar power. We are obtaining the finally $243 \mathrm{VAC}$ by Grid connected solar power system, in this way we are connected the Solar cells , controller, storage system as battery , invertor,

\section{References}

[1] F.Messai, H.Benallai "Modeling and simulation of grid connected photovoltaic distributed generation System", jatit, Vol. 45 No.2, 30th November 2012.

[2] Mahdi Salimi "Low-cost grid connected photovoltaic System", 2nd International Conference on Environmental Science and Technology, Singapore, IPCBEE vol.6, 2011. 
[3] Renewables 2012 "Global Status Report” REN21, 2012.

[4] Rohit Pandey, Dr. M.K.Gaur, Dr. C.S.Malvi "Estimation of cost analysis for 4Kw grids connected solar Photovoltaic Plant", International Journal of Modern Engineering Research, Vol.2, Issue.6, pp-4292-4294, Nov-Dec. 2012.

[5] A. Jusoh, "A Review on Favorable Maximum Power Point Tracking Systems in Solar Energy Application", TELKOMNIKA (Telecommunication Computing Electronics and Control), Vol. 12, No. 1, 2014, pp. 6-22. 